\title{
THE ADAPTABILITY OF THE GAS-FIRED COMPARTMENT KILN FOR THE BURNING OF CLAY PRODUCTS
}

\author{
BY W. D. RICHARDSON
}

\section{Introduction}

The most notable development in the clay industries of America in the past decade, especially in the latter half of it, is the increased attention given to fuel saving and the increased number of installations of the continuous, regenerative kiln. This has been due to the depletion of natural gas and the increase in the price of coal and fuel oil.

The burning of claywares on cars while they are being progressed through a tunnel, every cross section or vertical zone of which is constantly kept at the same temperature, is an ideal method that has been the dream of clayworkers for no one knows how long, at any rate long before my entrance into the industry. In fact, when $I$ first began the making of dry-pressed face brick, thirty-five years ago, of the half-dozen or so manufacturers who were then making a good quality of dry-pressed brick, one of them was burning his product in a tunnel kiln of his own invention. From that time I have known or been associated with three other men who have designed and patented tunnel kilns for burning brick. The first man, above mentioned, is the only one of these who was able to secure the capital for trying out his invention. He certainly put out some excellent brick but, as his plant was well fenced in and no visitors allowed, we can only guess why the business turned out to be a failure.

These remarks are not made to discredit the tunnel kiln, since these early inventors attacked the hardest problem, even for the tunnel kiln of today, that of burning the heavier and cruder products of the common, impure clays. The tunnel kiln, like every improvement in manufacturing processes, has been evolved from repeated failures. Undoubtedly further improvement in the tunnel kiln will make it most advantageous under some conditions and for some products.

It should be noted, however, that comparisons are made with the old periodic kiln and not with the latest developed continuous kilns of other types.

I have had several years' experience in the operation of the compartment kilns and have given considerable thought to their improvement. It is true, my experience with the compartment kiln has been entirely in the burning of face brick and hollow building tile, but since producer gas has become such a practical fuel for ceramic and metallurgical operations the compartment kiln can easily be adapted to the burning of any kind of ware and has a wider range of usefulness, as we will attempt to show, than any other type of kiln. 


\section{The Compartment Kiln}

It is understood that we mean by the compartment kiln a series of kilns, in juxtaposition, separated by a common wall and connected with each other by openings in the walls above or below the floor level, the kiln being in continuous operation, the air for combustion of fuel being heated by passing through compartments of the burnt ware back of the fire and the hot combusted gases passing through and preheating the compartments ahead of the fire. These kilns are sometimes built in a single row, but preferably in a double row, either in juxtaposition or separated. This continuous kiln was a later development of the Hoffman Ringofen or the anntular continuous tunnel or double row of parallel tunnels connected at both ends, now often built in this country as a single tunnel fired from the top and through doorways. This latter might properly be called the tunnel kiln and the so-called tunnel kiln be called the continuous car kiln or the continuous stationary-fire kiln.

The compartment kiln when direcl-fired with coal from the top was introduced into this country many years ago, one form coming from Scotland and one from Germany. When properly built and operated, it was a good kiln for brick, giving better results than the annula1 or continuous tunnel kiln, but costing more to build and keep in repair. This compartment kiln was fired with coal from the top into specially constructed fire boxes or combustion bags, on one or both sides of the compartment. The progress of the burning was rather slow, especially if high temperatures were required, since the combustion bags became more or less filled with ashes by the time the burning was finished and thus the flow of air to the fires through so mary of these bags was retarded.

\section{Importance of Producer Gas as Fuel}

The continuous compartment kiln could not have been presented today for the burning of pottery and refractories had it not been for the successful introduction of producer gas. Producer gas has made it practicable to design a compartment kiln for any ceramic product and makes this type of kiln deserving of consideration in any branch of the clay industry.

Producer gas can be conducted to any part of a compartment and in any quantity and its combustion controlled, so that any desired temperature may be reached quickly and oxidizing or reducing conditions maintained at will. As no ash is deposited on the ware and no flame need strike it, no protection for the ware is required.

Gas producers have been and are still made and sold that give serious trouble. Such producers have retarded a more extended use of producer gas, notwithstanding the fact that the making of good combustible 
gas from any fuel, wood, peat, lignite, bituminous or anthracite coal or oil, is a simple operation, and, when understood and with the proper equipment, involves very little labor or attention. Lignite and many bituminous coals cause much trouble in many producers from the formation of clinker, and some very elaborate mechanical producers can only be operated successfully on a coal giving an ash that slags at a high temperature. There need be no trouble in making good gas from any old coal, since we have learned to prevent the formation of clinker. To elucidate the gas producer problem would take us beyond the limits and purpose of this paper, which is to show that the compartment kiln, fired with producer gas, has a wide range of usefulness and in many cases is the most practical kiln.

\section{Experience with Gas-Fired Compartment Kiln}

The kilns that the writer has operated, in the burning of high-grade face brick, have compartments of such size that they could be filled with one gang of setters (two tossers and two setters) in two working days. This means that a compartment must be burned every two days. The compartments were two-side firing, 18 feet wide, 43 feet long and 10 feet high, from floor to top of crown inside. When the burning of a compartment was finished, the compartment next ahead of the fire would be redhot to the bottom and the second compartment ahear of the fire be incandescent half way to the floor and sometimes to the floor. The burners often finished in 36 hours and sometimes, with the more refractory brick, burning to cone 10 , in 24 hours' firing. The burning was always ahead of the setting and emptying and the burners and producer men regularly were. not on the job from Sunday morning to Monday morning.

During all my experience with the compartment kiln we were burning the same brick also by direct firing in periodic kilns, so that our yearly tabulations showed accurately the comparative consumption of coal in the two forms of kilns. The producer-gas-fired compartment kiln has required less than half of the amount of coal consumed in the periodic kilns. Moreover, the continuous kiln was much more uniform in results, since its operation is more systematic and under better control.

\section{Adaptability of Compartment Kiln to Pottery}

Since, in the burning of pottery wares, uniform results and quick operation are desirable, the compartments should not be too large, though they should probably be larger than most pottery men have been accustomed to. In any case, the compartment should be filled in one working day and burned in 24 hours' firing.

If it is desired to cool the compartments more rapidly, portable crowns 
may be used. Such crowns are entirely practical and have the advantage of costing less for repairs than the permanent crown.

One reason that many pottery manufacturers hesitate to install a compartment kiln, or continuous kiln of any kind, even in a new factory, is that it means a somewhat different method of handling the wares from the kiln. The solid row of compartments would block a direct passage from each kiln to the next department, requiring the ware from the bisque kilns being moved a farther distance to get them to the bisque warehouse or dipping room, and the ware from the glost kilns being moved a farther distance to the warehouse or packing room. This, however, does not mean any greater cost of handling, but a different system. Instead of the ware being carried by the kiln drawers to the next department, it must be placed by them on trucks or cars or continuous conveyors. If the kiln is built in a single row, with doors in both ends of each compartment as would generally be the case in a pottery, the conditions are most favorable for economic handling of wares, without conveyors.

\section{Summary}

The advantages of the continuous compartment kiln, gas-fired, are:

1. A saving of 60 to 70 per cent of the fuel used in periodic kilns under the best conditions.

2. A more compact kiln plant, less waste of space in the factory.

3. No coal to be distributed around the plant and no ashes to be removed from around kilns. All the coal unloaded mechanically at one place and ashes removed mechanically.

4. More rapid firing, a larger quantity of fuel can be introduced and no fuel fired in a compartment until it is red-hot throughout. In the compartment kiln, with induced draft, rapid progress can be made and oxidizing conditions maintained and the heat from the combusted gases utilized to the fullest extent in preheating the wares in the compartments ahead of the fire. In a tunnel kiln, whether of the stationary fire or progressing fire type, the capacity of the kiln is limited, since a strong draft does not distribute the heat properly and a weak draft, to overcome this, produces reducing conditions that are sometimes undesirable.

5. Better control of the burning, as compared with the periodic kiln, because of regulation at will of the gas and air, enabling the burning process to be reduced to a system. No special s kill required.

6. Greater uniformity of heat distribution-m ore uniform product.

7. Less cost for repairs than the periodic kiln and the advantage over the car tunnel kiln that repairs can be made without serious interruption of the operation of the kiln.

8. Less cost for operation per ton of ware burned. 
9. The advantage over the tunnel kiln that a greater variety of ware, as to size and temperature required, can be burned. Greater flexibility and adaptability. Any compartment may be filled with either bisque or glost ware without interfering with the regular operation of the kiln. The firing may be hastened or slowed up, as desired.

10. No delays due to the sticking of cars or damage to cars or to failure of mechanical pusher.

11. Ware not subject to motion or vibration, as in the car tunnel kiln.

12. No cars to be repaired or replaced.

13. No change in the regular method of placing kilns, though the work is made easier, since the bungs are not as high as in the old type of kilns.

14. The lower height of the bungs and the absence of abrupt heating increase the life of the saggers.

15. The bisque suffers no harm owing to sudden and rapid cooling, as is often the case in tunnel car kiln.

16. The ware may be warmed up by means of pure heated air drawn from cooling chambers, thus making it impossible to sulphur the goods.

While it is true that no single type or form of kiln is the best for all products and conditions, yet it is a fact that, we believe, cannot be controverted, that the compartment, gas-fired continuous kiln has a wider range of practical utility than any other form of kiln. 